\title{
KAJIAN YURIDIS PERLINDUNGAN PENGUNGSI DI INDONESIA SETELAH BERLAKUNYA PERATURAN PRESIDEN REPUBLIK INDONESIA NOMOR 125 TAHUN 2016 TENTANG PENANGANAN PENGUNGSI DARI LUAR NEGERI
}

\author{
Siciliya Mardian Yo'el \\ Fakultas Hukum Universitas Islam Kadiri (UNISKA) \\ Jalan Sersan Suharmaji No.38 Kediri, Jawa Timur, Indonesia
}

\begin{abstract}
Refugees are people who forced to leave his country out of fear from experiencing the persecution or murder he might endure if he chooses to live in his country. In international law these refugees are protected by the 1951 Refugee Convention and the 1967 Refugee Protocol. Indonesia does not ratify both of them so that Indonesia can refuse the arrival of refugees in its territory. Indonesia's strategic position has made Indonesia a transit country for refugees before they travel to countries that are parties to refugee conventions. For humanitarian reasons Indonesia then accommodate the refugees. Prior to the promulgation of Presidential Regulation nnumber 125, 2016 on the Handling of Refugees from Abroad, Indonesia does not have a legal instrument that regulates the handling of refugees. With the promulgation of this Presidential Regulation in 2016, Indonesia is expected to play a more important role in addressing refugee issues in the international world even though Indonesia has not ratified the 1951 Refugee Convention and the 1967 Refugee Protocol.
\end{abstract}

\begin{abstract}
ABSTRAK
Ada kalanya seseorang terpaksa meninggalkan negaranya karena rasa takut akan mengalami penganiayaan atau pembunuhan yang mungkin akan dialaminya jika dia memilih untuk tinggal di negaranya, orang-orang seperti ini kemudian dikenal sebagai pengungsi. Dalam hukum internasional keberadaan pengungsi ini dilindungi dengan Konvensi Pengungsi 1951 dan Protokol Pengungsi 1967. Indonesia tidak meratifikasi dan Protokol tersebut sehingga sebenarnya Indonesia berhak menolak kedatangan pengungsi di wilayahnya. Posisi Indonesia yang strategis membuat Indonesia dijadikan sebagai negara transit bagi pengungsi sebelum mereka melanjutkan perjalanan ke negara yang menjadi para pihak dalam konvensi pengungsi. Demi alasan kemanusiaan Indonesia kemudian menampung para pengungsi tersebut. Sebelum diundangkannya Perpres No. 125 Tahun 2016 tentang Penanganan Pengungsi dari Luar Negeri, Indonesia tidak memiliki instrument hukum yang mengatur tentang penanganan pengungsi. Dengan diundangkannya Perpres ini pada 2016, Indonesia diharapkan bisa lebih berperan dalam menangani masalah pengungsi di dunia internasional meskipun Indonesia belum meratifikasi Konvensi Pengungsi 1951 dan Protokol Pengungsi 1967. Dapat ditarik kesimpulan bahwa Indonesia telah memiliki dasar hukum dalam penanganan pengungsi yang memasuki wilayah Indonesia dan tidak lagi terjadi kekosongan hukum.
\end{abstract}




\section{A. PENDAHULUAN}

\section{Latar Belakang Masalah}

Perpindahan atau migrasi manusia dari satu tempat ke tempat lain telah berlangsung selama ribuan tahun. Perpindahan orang dari suatu negara menuju negara lain yang bukan merupakan negara tempat ia memiliki kewarganegaraan ini disebut sebagai imigrasi. ${ }^{76}$ Sedangkan pelakunya disebut sebagai imigran. Imigrasi bisa dilakukan dengan cara legal ataupun ilegal. ${ }^{77}$ Ada banyak faktor yang menyebabkan imigrasi, salah satunya adalah untuk mendapatkan kehidupan yang lebih baik. Ada kalanya imigrasi ini dilakukan bukan karena kemauan pribadi tapi karena daya paksa, seseorang terpaksa meninggalkan negaranya karena rasa takut akan mengalami penganiayaan atau pembunuhan yang mungkin akan dialaminya jika dia memilih untuk tinggal di negaranya. Mereka yang terpaksa meninggalkan negaranya ini umumnya disebut sebagai pengungsi. ${ }^{78}$

UNHCR (United Nations High Commisioners for Refugees) adalah badan milik Perserikatan Bangsa-Bangsa (PBB) yang berhak menilai layak tidaknya seseorang yang mencari suaka untuk diberikan status sebagai pengungsi. Ada dua instrument internasional yang digunakan untuk menilai kelayakan seseorang agar dapat dikategorikan sebagai pengungsi, pertama adalah Geneva Convention Relating to The Status of Refugees 1951 (selanjutnya disebut sebagai Konvensi Pengungsi 1951) dan New York Protocol Relating to The Status of Refugees 1967 (selanjutnya disebut sebagai Protokol Pengungsi 1967).

${ }^{76}$ Lihat pengertian tentang Imigrasi di http://id.wikipedia.org/wiki/imigrasi

${ }^{77}$ Status legal dan illegal seorang imigran ditentukan oleh dokumen-dokumen imigrasi yang dimiliki oleh imigran tersebut. Jika seorang imigran masuk ke sebuah Negara dengan membawa dokumen imigrasi yang resmi, maka dia disebut imigran yang legal. Sebaliknya, jika seseorang masuk ke sebuah negara tanpa dokumen imigrasi yang resmi, maka dia disebut sebagai imigran illegal.

${ }^{78}$ Penyebutan istilah pengungsi disini adalah dalam konteks umum, bukan pengertian dalam peraturan perundang-undangan/ Hukum Internasional. Lihat Arbi Sumandoyo dkk, "Nasib Tanpa Negara Para Pencari Suaka di Indonesia", https://tirto.id/nasib-tanpa-negara-para-pencari-suaka-diindonesia-cqgr, diakses tanggal 8 Oktober 2017 
Data UNHCR menunjukkan bahwa pada akhir tahun 2015, terdapat 65,3 juta manusia yang melakukan perpindahan karena terpaksa. ${ }^{79}$ Dari jumlah tersebut, sampai bulan Maret 2017 UNHCR Jakarta mencatat ada 6.191 pencari suaka dan 8.279 pengungsi yang berada di Indonesia. ${ }^{80}$ Indonesia sendiri sebenarnya bukanlah Negara peserta (tidak meratifikasi) Konvensi Pengungsi 1951 dan Protokol Pengungsi 1967. Ini artinya Indonesia tidak terikat dengan dua peraturan tersebut dan sebenarnya tidak memiliki kewajiban untuk menampung para pengungsi yang datang ke Indonesia.

UNHCR sendiri menjelaskan bahwa posisi Indonesia adalah sebagai negara transit. ${ }^{81}$ Indonesia selalu banyak didatangi oleh pengungsi yang memiliki tujuan ke Australia, mengingat posisi Indonesia yang cukup strategis untuk beristirahat, karena jarak dari negara asal sangatlah jauh dengan negara tujuan. ${ }^{82}$ Dengan demikian, sebagai negara transit dan bukan negara pihak dalam Konvensi Pengungsi 1951 dan Protokol Pengungsi 1967, Indonesia tidak dapat dimintai pertanggungjawaban dalam hukum internasional. Ketika para pengungsi mencapai wilayah Indonesia, maka secara Hukum Internasional sebenarnya Indonesia tidak memiliki tanggung jawab sama sekali terhadap pengungsi. Para pengungsi tersebut tidak bisa mendapatkan kesejahteraan dalam apapun dari pemerintah Indonesia. ${ }^{83}$

Meskipun demikian, dengan alasan kemanusiaan, pemerintah Indonesia tidak mungkin mengabaikan atau menelantarkan pengungsi yang telah sampai

${ }^{79}$ Data berdasarkan Press Release UNHCR 20 Juni 2016, http://www.unhcr.org/id, diakses tanggal 8 Oktober 2017

80 UNHCR Indonesia, UNHCR di Indonesia, http://www.unhcr.org/id/unhcr-di-indonesia, diakses tanggal 8 Oktober 2017

${ }^{81}$ Loc.Cit,

82 Sherly Puspita, Ini Alasan Para Pencari Suaka Tertarik Singgah di Indonesia, http://megapolitan.kompas.com/read/2017/06/21/06300541/ini.alasan.para.pencari.suaka.tertarik.singg ah.di.indonesia, diakses tanggal 8 Oktober 2017.

${ }^{83}$ Negara yang menjadi pihak dalam Konvensi Pengungsi 1951 memiliki kewajiban untuk memberikan perlakuan yang sama terhadap pengungsi seperti warga negaranya sendiri. Lihat Pasal 24 (1) Konvensi Pengungsi 1951 yang selengkapnya berbunyi: "The Contracting States shall accord to refugees lawfully staying in their territory the same treatment as is accorded to nationals in respect of the following matters". 
ke wilayah Negara Kesatuan Republik Indonesia. Karena salah satu tujuan dari Negara Indonesia adalah ikut melaksanakan ketertiban dunia yang berdasarkan perdamaian abadi dan keadilan sosial, yang tercantum dalam Pembukaan Undang-Undang Dasar (UUD) 1945. Tujuan ini kemudian diperjelas lagi dalam batang tubuh UUD 1945 yakni pada Pasal 28 G ayat $2 .{ }^{84}$ Hal inilah yang menjadi dasar perlindungan hukum bagi pengungsi di Indonesia. Jaminan hak untuk memperoleh suaka atau perlindungan hukum di Indonesia diperkuat oleh Pasal 28 (1) UU No. 39 Tahun 1999 tentang Hak Asasi Manusia, ${ }^{85}$ serta ketentuan dalam Pasal 25 dan 27 UU No. 37 Tahun 1999 tentang Hubungan Luar Negeri. ${ }^{86}$

Pada 31 Desember 2016, Pemerintah Indonesia mengesahkan Peraturan Presiden (Perpres) Republik Indonesia Nomor 125 Tahun 2016 tentang Penanganan Pengungsi dari Luar Negeri. ${ }^{87}$ Penerbitan Perpres tersebut merupakan sebuah kemajuan setelah lama direncanakan sejak tahun $2010 .^{88}$ Secara normatif, Perpres ini mengisi kekosongan hukum pengaturan pengungsi dan pencari suaka di Indonesia yang ditegaskan di dalam Pasal 28 G (2) UUD 1945 dan Pasal 25 dan 27 UU No. 37 Tahun 1999 tentang Hubungan Luar Negeri.

${ }^{84}$ Pasal 28 G (2) UUD 1945 berbunyi, "Setiap orang berhak untuk bebas dari penyiksaan atau perlakuan yang merendahkan derajat martabat manusia dan berhak memperoleh suaka politik dari negara lain".

${ }^{85}$ Pasal 28 (1) UU No. 39 Tahun 1999 tentang Hak Asasi Manusia berbunyi, "Setiap orang berhak mencari suaka untuk memperoleh perlindungan politik dari Negara lain".

${ }^{86}$ UU No. 37 Tahun 1999 tentang Hubungan Luar Negeri; Pasal 25 (1) Kewenangan pemberian suaka kepada orang asing berada di tangan Presiden dengan memperhatikan pertimbangan Menteri; (2) Pelaksanaan kewenangan sebagaimana dimaksud dalam ayat (1) diatur dengan Keputusan Presiden; Pasal 27 (1) Presiden menetapkan kebijakan masalah pengungsi dari luar negeri dengan memperhatikan pertimbangan Menteri. (2) Pokok- pokok kebijakan sebagaimana dimaksud dalam ayat (1) diatur dengan Keputusan Presiden.

${ }^{87}$ Rakyat Merdeka Online, "Perpres Perlindungan Pengungsi Harus Menjawab Permasalahan Pencari Suaka di Indonesia, http://dunia.rmol.co/read/2017/01/18/277051/Perpres-PerlindunganPengungsi-Harus-Menjawab-Permasalahan-Pencari-Suaka-di-Indonesia-, diakses tanggal 8 Oktober 2017

$$
{ }^{88} \text { Loc.Cit }
$$




\section{Rumusan Masalah}

Bagaimana perlindungan pengungsi di Indonesia setelah berlakunya Peraturan Presiden (Perpres) Republik Indonesia Nomor 125 Tahun 2016 tentang Penanganan Pengungsi dari Luar Negeri.

\section{Tujuan Penelitian}

Untuk mendeskripsikan perlindungan pengungsi di Indonesia setelah berlakunya Peraturan Presiden (Perpres) Republik Indonesia Nomor 125 Tahun 2016 tentang Penanganan Pengungsi dari Luar Negeri.

\section{B. PEMBAHASAN}

\section{Dasar Hukum Perlindungan Pengungsi di Indonesia Sebagai Negara} Transit Sebelum Perpres No. 125 Tahun 2016

Dalam Hukum Internasional, seseorang tidak bisa langsung mendapatkan status sebagai pengungsi. Sebelum dinyatakan sebagai pengungsi, biasanya para imigran ini terlebih dahulu berstatus sebagai "stateless person". 89 Kondisi "stateless" ini umumnya disebabkan oleh ketidakmampuan orang tersebut untuk menunjukkan dokumen yang berkaitan dengan kewarganegaraannya, dan atau dokumen-dokumen imigrasi penunjang untuk melakukan perjalanan ke luar negeri. ${ }^{90}$ Umumnya mereka ini meninggalkan negaranya dalam kondisi yang genting, sehingga sangat sulit untuk mereka bisa mendapatkan dokumen imigrasi yang memadai. ${ }^{91}$ Menjadi "stateless" dapat membuat seseorang kehilangan hak-hak sebagai warganegara.

89 Stateless person dapat diartikan sebagai seseorang yang tidak memiliki kewarganegaraan. Kondisi tanpa kewarganegaraan ini dapat terjadi karena orang tersebut gagal menunjukkan dokumendokumen yang berkaitan dengan status kewarganegaraannya, atau karena dokumen-dokumen tersebut dicabut/ dinyatakan tidak berlaku lagi oleh negara asalnya.

90 Arbi Sumandoyo dkk, "Nasib Tanpa Negara Para Pencari Suaka di Indonesia", https://tirto.id/nasib-tanpa-negara-para-pencari-suaka-di-indonesia-cqgr, diakses tanggal 8 Oktober 2017

91 Institute for Criminal Justice Reform, "Melihat Perlindungan Pengungsi di Indonesia", http://icjr.or.id/melihat-perlindungan-pengungsi-di-indonesia/, diakses tanggal 8 Oktober 2017 
Kewarganegaraan adalah salah satu hak asasi manusia yang tercantum dalam UN Declaration of Human Rights 1948, hak untuk mendapatkan kewarganegaraan ini diatur dalam Pasal 15. ${ }^{92}$ Dengan demikian maka sudah seharusnya seseorang yang berstatus sebagai stateless person bisa mendapatkan kewarganegaraan baru sebagai bagian dari hak asasinya. Dengan mendapatkan kewarganegaraan ini maka hak-hak lainnya dapat terpenuhi. Untuk mendapatkan kewarganegaraan (baik lama atau baru), seorang imigran dapat mengajukan suaka, atau mendapatkan status sebagai "pengungsi". ${ }^{93}$ Konvensi Pengungsi 1951, mendefinisikan pengungsi sebagai:

"Seseorang yang dikarenakan oleh ketakutan yang beralasan akan penganiayaan, yang disebabkan oleh alasan ras, agama, kebangsaan, keanggotaan kelompok sosial tertentu dan keanggotaan partai politik tertentu, berada di luar negara kebangsaannya dan tidak menginginkan perlindungan dari negara tersebut." 94

Berdasarkan definisi ini, tidak semua imigran, stateless person dan pencari suaka dapat dikategorikan sebagai pengungsi. Status pengungsi hanya bisa diberikan oleh UNHCR berdasarkan kriteria-kriteria tertentu. Salah satu kriteria pengungsi adalah orang yang terpaksa meninggalkan negara asalnya karena rasa takut yang mendasar dan mengalami persekusi/ penindasan. Adanya rasa takut yang mendasar inilah yang membuat pengungsi berbeda dengan imigran lainnya. ${ }^{95}$

Indonesia memiliki posisi strategis karena terletak di antara benua Asia dan Australia, juga diantara Samudera Hindia dan Samudera Pasifik. Posisi ini membuat Indonesia sering dijadikan tempat transit bagi pengungsi dari kawasan yang sedang dilanda konflik (Timur Tengah dan Asia Selatan)

${ }^{92}$ Lengkapnya UN Declaration of Human Rights1948 pada Pasal 15 ini berbunyi: (1) Everyone has the right to a nationality, (2) No one shall be arbitrarily deprived of his nationality nor denied the right to change his nationality.

${ }_{93}$ Dalam konteks Hukum Internasional

${ }^{94}$ UNHCR Indonesia, "Pengungsi", www.unhcr.or.id, diakses pada 8 Oktober 2017

${ }^{95}$ Wagiman, Hukum Pengungsi Internasional, (Jakarta: Sinar Grafika, 2012), hlm. 52. 
menuju Australia.9 ${ }^{96}$ Sebenarnya, sebagai negara transit Indonesia tidak mempunyai dasar agar dapat dimintai pertanggungjawaban terhadap pengungsi yang masuk wilayahnya berdasarkan aturan internasional. Meskipun demikian, Indonesia tentu tidak dapat lepas tangan begitu saja jika ada pencari suaka atau pengungsi yang masuk ke wilayah Indonesia. Saat ini berdasarkan data UNHCR per Januari 2017, jumlah pencari suaka dan pengungsi di Indonesia sekitar 14.425 orang, terdiri dari 8.039 pengungsi dan 6.386 pencari suaka. ${ }^{97}$ Dari jumlah tersebut ada 2.177 orang yang ditahan di rumah detensi imigrasi, 2.030 orang di kantor Imigrasi, 4.225 orang di rumah komunitas, dan sisanya, 5.993 orang digolongkan sebagai imigran mandiri. ${ }^{98}$

Keberadaan pengungsi di Indonesia bukanlah hal yang asing. Persinggungan pertama Indonesia dengan masalah pengungsi terjadi pada kurun waktu 1975-1980, saat Indonesia menerima pengungsi dari Vietnam dan menempatkan mereka di Pulau Galang, Propinsi Riau. ${ }^{99}$ Pada saat itu, pemberian bantuan terhadap pengungsi secara yuridis didasarkan pada Keputusan Presiden dan merujuk pada hukum internasional. ${ }^{100}$ Sebagai anggota $\mathrm{PBB}$, Indonesia bekerja sama dengan UNHCR untuk mengatasi masalah pengungsi. Di negara yang telah meratifikasi konvensi dan protokol pengungsi, UNHCR hanya menjadi supervisi sehingga negara tersebut dapat menerapkan sistemnya sendiri dalam menerima pencari suaka dan memberikan status pengungsi. Untuk Negara yang belum meratifikasi,

96 Australia adalah salah satu negara peratifikasi Konvensi Pengungsi 1951 dan Protokol Pengungsi 1967. Australia sering dipilih oleh para pengungsi dari kawasan Asia karena lokasinya yang relatif dekat dan tergolong sebagai negara maju. Sherly Puspita, Op.Cit, diakses tanggal 8 Oktober 2017

97 Arbi Sumandoyo dkk, Op.Cit, diakses tanggal 8 Oktober 2017

${ }^{98}$ Imigran mandiri adalah mereka yang meninggalkan negaranya dan mencari suaka di negara lain tetapi tidak tergantung pada UNHCR untuk memenuhi kebutuhan hidup mereka. Loc.cit.

99 Pengungsi dari Vietnam ini dikenal dengan sebutan Vietnamese Boat People, yang mengungsi sebagai akibat Perang Vietnam. Rosmawati, "Perlindungan Terhadap Pengungsi/ Pencari Suaka di Indonesia (Sebagai Negara Transit) Menurut Konvensi 1951 dan Protokol 1967”, Jurnal Ilmu Hukum Universitas Syiah Kuala, Volume 17, Nomor 3, 2015, hlm. 2

${ }^{100}$ Loc.cit. 
UNHCR berperan melayani pencari suaka dan memberikan status pengungsi. ${ }^{101} \mathrm{Di}$ Indonesia sendiri, penentuan status pencari suaka dan pengungsi dilakukan oleh UNHCR.

Pengungsi yang datang ke wilayah suatu negara pada prinsipnya memiliki hak untuk tidak dikembalikan ke negara asalnya, atau dikirim ke negara lain dimana keselamatan para pengungsi itu tidak dijamin. ${ }^{102}$ Prinsip ini dikenal dengan prinsip non-refoulement yang diatur dalam Pasal 33 (1) Konvensi Pengungsi $1951 .^{103}$ Pada dasarnya prinsip non-refoulement ini adalah kewajiban bagi negara peratifikasi konvensi untuk tidak mengembalikan pengungsi ke wilayah dimana persekusi terhadap mereka terjadi, tetapi juga bukan berarti ada kewajiban bagi negara penerima pengungsi untuk menjamin tempat tinggal yang stabil dalam jangka waktu yang panjang. ${ }^{104}$ Prinsip non-refoulement ini telah menjadi hukum kebiasaan internasional, sehingga mengikat seluruh negara di dunia termasuk mereka yang tidak meratifikasi Konvensi Pengungsi $1951 .{ }^{105}$ Dengan demikian, saat Indonesia kedatangan pengungsi di wilayahnya, Indonesia harus menerima keberadaan pengungsi tersebut dan tidak dapat dengan serta merta mendeportasi pengungsi tersebut kembali ke negaranya, atau mengirim pengungsi tersebut ke negara lain dimana keselamatan para pengungsi tersebut tidak dapat dijamin.

Selain hak untuk tidak dikembalikan ke negara asalnya, pengungsi juga memiliki hak-hak lain, yakni: kebebasan menjalankan agama (Pasal 4), akses

101 Fitria, "Perlindungan Hukum Bagi Pengungdi di Negara Ketiga: Praktik Indonesia", Padjajaran Jurnal Ilmu Hukum, Volume 2 Nomor 1, 2015, hlm. 110

102 Loc.cit,

1031951 Geneva Convention Relating to The Status of Refugees, Article 33, Prohibition of expulsion or return ("refoulement"), (1) No Contracting State shall expel or return ("refouler") a refugee in any manner whatsoever to the frontiers of territories where his life or freedom would be threatened on account of his race, religion, nationality, membership of a particular social group or political opinion.

${ }^{104}$ Fitria, Op.Cit, hlm. 110

${ }^{105}$ Loc.Cit. Lihat juga, Rosmawati, Op.Cit, hlm. 18 
ke pengadilan dan bantuan hukum (Pasal 16), jaminan sosial (Pasal 24), dokumen perjalanan (Pasal 28), dan kemudahan untuk proses naturalisasi (Pasal 34). ${ }^{106}$ Berbeda dengan hak yang melekat pada prinsip nonrefoulement yang kemudian disepakati menjadi hukum kebiasaan internasional, hak-hak lain ini hanya diwajibkan kepada negara-negara yang telah meratifikasi Konvensi Pengungsi 1951 saja. Dengan demikian, para pengungsi yang datang ke wilayah Indonesia tidak berhak mendapatkan atau menuntut hak-haknya yang lain (seperti yang tercantum dalam Konvensi Pengungsi 1951) kepada pemerintah negara Republik Indonesia ${ }^{107}$.

Berdasarkan Hukum Internasional, sebagai negara bukan peratifikasi Konvensi Pengungsi 1951 dan Protokol Pengungsi 1967 Indonesia sebenarnya memiliki hak sebagai negara merdeka untuk menerapkan kedaulatannya dan menentukan apakah Indonesia berkenan atau tidak menerima pengungsi untuk masuk ke wilayah Indonesia. Tindakan tersebut dapat dianggap sebagai langkah preventif atau sebagai bentuk pertahanan negara dari gangguan asing, demi melindungi dan menjaga stabilitas ekonomi dan politik negara, terutama bagi Indonesia sebagai negara berkembang. ${ }^{108}$

Indonesia memandang dan menyikapi persoalan pengungsi sebagai persoalan Hak Asasi Manusia yang bersifat universal. Sebagai anggota aktif Perserikatan Bangsa-Bangsa (PBB), Indonesia memiliki tanggung jawab untuk menegakkan dan menjunjung tinggi hak-hak asasasi manusia (HAM), bukan hanya bagi warga negara Indonesia, tetapi juga bagi masyarakat dunia sebagai perwujudan dari tujuan bangsa Indonesia seperti yang tercantum dalam alinea 4 pembukaan UUD $1945 .^{109}$ Indonesia memiliki komitmen

${ }^{106}$ Lihat 1951 Geneva Convention on The Status of Refugees, Article 4, 16, 24, 28 dan 34.

107 Selain hak untuk tidak dikembalikan pada negara asalnya.

${ }^{108}$ Rosmawati, Op.Cit, hlm. 5

109 Lembar Disposisi Direktur HAM dan Kemanusiaan, Naskah Akademik Rancangan Undang-Undang Pengesahan Konvensi Pengungsi, (Jakarta: Direktorat Kerjasama HAM Kementerian Hukum dan Hak Asasi Manusia Republik Indonesia, 2010), hlm.12. 
terhadap perlindungan, penegakan, pemenuhan serta pemajuan HAM. ${ }^{110}$ Termasuk didalamnya adalah HAM bagi para pengungsi yang berada di wilayah Indonesia.

Sebelum periode 2016, perlindungan pengungsi di Indonesia belum mempunyai dasar hukum tersendiri. Perlindungan pengungsi di Indonesia berdasarkan perangkat hukum yang berasaskan HAM seperti :

UUD 1945, Pasal 28 G (2), bahwa setiap orang berhak untuk bebas dari penyiksaan atau perlakuan yang merendahkan derajat martabat manusia dan berhak memperoleh suaka politik dari negara lain

Tap MPR No. XVII/MPR/1998, salah satu bagian dari TAP MPR ini adalah pengakuan terhadap Deklarasi Hak Asasi Manusia yang dalam Pasal 24 menyatakan bahwa setiap orang berhak mencari suaka untuk memperoleh perlindungan politik dari negara lain.

UU No. 5 Tahun 1998 tentang Pengesahan (Ratifikasi) Convention Againts Torture and Other Cruel, In Human or Degrading Treatment or Punishment, dalam Pasal 3 konvensi ini disebutkan bahwa negara pihak dilarang melakukan tindakan non refoulment, pengusiran, repatriasi/pengembalian atau pengekstradisian seseorang ke negara lain. Maka setiap pencari suaka harus diterima oleh negara dimana individu tersebut memohon suaka.

UU No. 37 Tahun 1999 tentang Hubungan Luar Negeri mengatur tentang pengungsi, ada dua pasal yang membahas tentang pengungsi, yakni: Pasal 25 (1) yang menyatakan bahwa Presiden berwenang memberikan suaka kepada orang asing, dan Pasal 27 (1) yang menyatakan bahwa presiden menetapkan kebijakan masalah pengungsi dari luar negeri dengan memperhatikan pertimbangan menteri..

${ }^{110}$ Loc.Cit, 
UU No. 39 Tahun 1999 tentang Hak Asasi Manusia, menyatakan dalam Pasal 28 (1) disebutkan bahwa setiap orang berhak mencari suaka untuk memperoleh perlindungan politik dari negara lain.

Pada periode ini, meskipun Indonesia tidak memiliki peraturan perundang-undangan yang secara khusus membahas tentang perlindungan terhadap pengungsi yang ada di Indonesia, tetapi Indonesia memiliki peraturan perundang-undangan lain yang memungkinkan pengungsi dan pencari suaka untuk memasuki wilayah Indonesia. Peraturan perundangundangan di atas juga menunjukkan bahwa Indonesia memiliki komitmen pada prinsip non-refulement terhadap pengungsi sebagai bagian dari hak asasi manusia mereka. Meskipun Indonesia tidak meratifikasi Konvensi Pengungsi 1951 dan Protokol Pengungsi 1967, tetapi Indonesia telah menunjukkan komitmen untuk menangani kasus pengungsi dan penacari suaka yang masuk dalam wilayah Indonesia. Dalam hal penanganan pengungsi dan pencari suaka ini Indonesia bekerja sama dengan International Organization of Migration (IOM), UNHCR, dan Pemerintah Australia. ${ }^{111}$

Kementerian Luar Negeri Indonesia sebagai perwakilan pemerintah, berkoordinasi dengan UNHCR dan IOM dalam menjalankan fungsinya untuk menangani pengungsi tersebut diantaranya adalah, (1) mencarikan negara yang bersedia menampung pengungsi. Pada prakteknya hal ini bukanlah sesuatu yang mudah, karena negara-negara yang biasa menampung pengungsi seperti di Eropa saat ini tengah menghadapi masalah yang sama tentang membludaknya pengungsi yang datang di kawasan ini. ${ }^{112}$ (2) Sharing burden (pembagian beban) yang dilakukan oleh Pemerintah Indonesia bersama Pemerintah Australia. Pemerintah Australia sebagai negara tujuan pengungsi memberikan bantuan terhadap pemerintah Indonesia untuk menangani pengungsi tersebut di Indonesia sambil menunggu penempatan

\footnotetext{
${ }^{111}$ Fitria, Op.Cit, hlm. 116 - 117

${ }^{112}$ Rosmawati, Op.Cit, hlm. 26
} 
pengungsi oleh UNHCR. ${ }^{113}$ (3) Mengembalikan pengungsi ke negara asal. ${ }^{114}$ Selain itu Indonesia juga menyiapkan instrument hukum yang terkait dengan pencari suaka dan pengungsi. Instrumen hukum ini diharapkan dapat menjadi payung hukum bagi pemerintah Indonesia dalam menangani pengungsi dan pencari suaka yang masuk ke wilayah Indonesia.

\section{Perlindungan Pengungsi di Indonesia Menurut Peraturan Presiden Republik Indonesia Nomor 125 Tahun 2016 Tentang Penanganan Pengungsi dari Luar Negeri}

Berdasarkan uraian di atas telah dijelaskan sebelumnya bahwa dalam hukum internasional, penanangan masalah pengungsi diatur dalam Konvensi Pengungsi 1951 dan Protokol Pengungsi 1957. Negara-negara yang telah meratifikasi dua instrument hukum tentang pengungsi berkewajiban menerapkan aturan-aturan yang ditetapkan dalam konvensi tersebut dalam hukum hukum nasionalnya. Indonesia sendiri sampai saat ini belum meratifikasi keduanya.

Dasar pertimbangan Indonesia yang paling besar adalah faktor ekonomi. Indonesia adalah negara berkembang yang belum memiliki kemampuan dalam memperlakukan pengungsi sesuai pengaturan yang tertera di dalam konvensi. Ketentuan konvensi dan protokol pengungsi mengatur bahwa pemerintah negara yang telah meratifikasi keduanya memiliki tanggung jawab guna menjamin keberlangsungan hidup pengungsi di negaranya. Kewajibankewajiban yang dibebankan kepada negara peratifikasi ini memilik dimensi luas, bukan saja dalam aspek hak ekonomi dan sosial bagi para pengungsi, namun juga termasuk hak sipil dan politik pengungsi yang tinggal di negara tersebut. $^{115}$ Dapat dikatakan bahwa sebelum tahun 2016 Indonesia memiliki

${ }^{113}$ Fitria, Op.Cit, hlm. 113

114 Indonesia menghormati prinsip non-refoulement yang menjadi hukum kebiasaan internasional, tetapi dalam prakteknya Indonesia pada tahun 2015 memulangkan pengungsi asal Rohingya dan Bangladesh kembali ke negaranya. Lihat Rosmawati, Op.Cit, hlm. 27

${ }^{115}$ Fitria, Op.Cit, hlm. 114 
kekosongan hukum dalam hal penanganan pengungsi yang masuk di wilayah Indonesia. Penanganan pengungsi hanya didasarkan pada peraturan perundang-undangan yang mengatur tentang HAM yang di dalamnya juga termasuk hak-hak untuk pengungsi.

Pemerintah Indonesia akhirnya mengesahkan Peraturan Presiden (Perpres) Republik Indonesia Nomor 125 Tahun 2016 tentang Penanganan Pengungsi dari Luar Negeri Pada 31 Desember 2016 (selanjutnya disebut dengan Perpres). ${ }^{116}$ Secara normatif, Perpres ini mengisi kekosongan hukum pengaturan pengungsi dan pencari suaka di Indonesia yang ditegaskan di dalam Pasal 28 G (2) UUD 1945 dan Pasal 25 dan 27 UU No. 37 Tahun 1999 tentang Hubungan Luar Negeri. Dengan ditandatanganinya Perpres ini oleh Presiden Joko Widodo, maka Indonesia tidak lagi menagalami kekosongan hukum dalam hal menangani pengungsi yang masuk ke wilayahnya.

Sebelum berlakunya perpres ini, sistem hukum Indonesia, berdasarkan UU No. 6 Tahun 2011 tentang Keimigrasian, masih mengkategorikan pengungsi sebagai imigran ilegal atau imigran yang memasuki wilayah Indonesia tanpa dokumen keimigrasian yang resmi. ${ }^{117}$ Menurut undangundang ini, para pengungsi yang masuk ke wilayah Indonesia selalu dikenakan tindakan keimigrasian dalam bentuk penahanan selama jangka waktu maksimum 10 tahun di rumah detensi imigrasi yang tersebar di beberapa lokasi di seluruh Indonesia. ${ }^{118}$ Hal ini tentu saja bertentangan dengan hukum internasional yang berlaku dimana seorang pengungsi tidak dapat disamakan dengan imigran illegal lainnya, karena pengungsi adalah orang yang terpaksa meninggalkan wilayah negaranya karena ketakutan terhadap

\footnotetext{
${ }^{116}$ Rakyat Merdeka Online, Op.Cit, diakses tanggal 8 Oktober 2017

${ }^{117}$ UU No. 6 Tahunn 2011 tentang Keimigrasian menggunakan istilah "Orang Asing” untuk menyebut orang yang bukan warga negara Indonesia (Pasal 1 butir 9). Status "orang asing" di Indonesia dapat dibagi dua. Orang Asing yang masuk ke wilayah Indonesia dengan menggunakan dokumen imigrasi yang resmi/ legal. Dan orang asing yang masuk wilayah Indonesia tanpa dokumen resmi (illegal).

${ }^{118}$ Institute for Criminal Justice Reform, Op.Cit, diakses tanggal 8 Oktober 2017
} 
ancaman persekusi. Dalam kondisi demikian seorang pengungsi tentu kesulitan untuk mengurus dokumen perjalanan/ imigrasi yang diperlukan untuk memasuki wilayah negara tertentu.

Sebelum Perpres diterbitkan mekanisme penanganan pengungsi dilakukan berdasarkan Peraturan Dirjen Imigrasi No. IMI-1489.UM.08.05 Tahun 2010 tentang Penanganan Imigran Illega. Dalam peraturan ini disebutkan bahwa setiap pengungsi yang masuk ke Indonesia akan dikenakan tindakan keimigrasian dalam bentuk penahanan sampai status pengungsinya ditetapkan oleh UNHCR. Hal tersebut berimbas pada munculnya pelanggaran hak pengungsi, karena pengungsi bukanlah pelaku kriminal namun ditempatkan pada situasi yang mirip dengan penahanan pelaku tindakan kriminal (dalam rumah detensi imigrasi/ rudenim). ${ }^{119}$ Dengan diterbitkannya Perpres No. 125 Tahun 2016 tentang Penanganan Pengungsi dari Luar Negeri ini diharapkan penanganan pengungsi di Indonesia dapat berubah kearah yang lebih baik dan hak-hak pengungsi lebih terakomodir selama berada di Indonesia.

Dalam Perpres No. 125 Tahun 2016 tentang Penanganan Pengungsi dari Luar Negeri, penanganan pengungsi di Indonesia dilakukan berdasarkan kerja sama antara pemerintah pusat dengan PBB melalui UNHCR di Indonesia dan/atau organisasi internasional di bidang urusan migrasi atau di bidang kemanusiaan yang memiliki perjanjian dengan pemerintah pusat. ${ }^{120}$ Kementrian yang bertanggung jawab dalam masalah penanganan para pengungsi ini adalah Kementrian Koordinator Politik, Hukum dan Keamanan (Kopolhukam), Kementerian Hukum dan Hak Asasi Manusia serta

119 Loc.Cit, Menurut laporan Institute for Criminal Justice Reform, banyak di antara pengungsi yang mengalami tekanan psikologis dan berkeinginan kuat untuk bunuh diri atau kabur dari rumah detensi imigrasi tersebut. Pada 13 November 2011, sebanyak 13 pengungsi dan pencari suaka kabur dari Rudenim Tanjungpinang. Seorang dari mereka gagal menembus kawat berduri Rudenim dan tewas, sementara seorang lainnya yang juga gagal kabur mengalami luka parah.

${ }^{120}$ Pasal 2 ayat (1) dan (2), Perpres No. 125 Tahun 2016 tentang Penanganan Pengungsi dari Luar Negeri 
Kementrian Luar Negeri. ${ }^{121}$ Koordinasi yang berkaitan dengan penemuan, penampungan, pengamanan dan pengawasan keimigrasian dilakukan oleh Menkopolhukam dan perumusan kebijakannya mendapat pertimbangan dari Menteri Luar Negeri. ${ }^{122}$

Perpres ini juga memberikan batasan serta definisi yang jelas tentang pengungsi, yakni adalah orang asing yang berada di wilayah Negara Kesatuan Republik Indonesia disebabkan karena ketakutan yang beralasan akan persekusi dengan alasan ras, suku, agama, kebangsaan, keanggotaan kelompok sosial tertentu, dan pendapat politik yang berbeda serta tidak menginginkan perlindungan dari negara asalnya dan/atau telah mendapatkan status pencari suaka atau status pengungsi dari PBB melalui UNHCR di Indonesia. ${ }^{123}$ Dengan demikian, maka pengungsi tidak akan disamakan lagi dengan imigran ilegal lainnya. Perpres ini juga menyatakan bahwa penanganan pengungsi harus dilakukan dengan memperhatikan ketentuan internasional yang berlaku umum dan sesuai dengan ketentuan peraturan perundang-undangan. ${ }^{124}$ Dengan demikian, maka penanganan pengungsi di Indonesia harus merujuk pada ketentuan yang ada di dalam Konvensi Pengungsi 1951 dan Protokol Pengungsi 1967 selama tidak bertentangan dengan peraturan perundang-undangan yang berlaku di Indonesia.

Perlindungan terhadap pengungsi dalam perpres ini dilakukan sejak kedatangan pengungsi di wilayah Indonesia. Pengungsi datang ke wilayah Indonesia umumnya melalui laut. ${ }^{125}$ Sehingga dalam perpres ini diatur

${ }^{121}$ Pasal 1 butir 5 dan 7, Pasal 4 ayat (3), Perpres No. 125 Tahun 2016 tentang Penanganan Pengungsi dari Luar Negeri

${ }^{122}$ Pasal 4 ayat (1), (2) dan (3) Perpres No. 125 Tahun 2016 tentang Penanganan Pengungsi dari Luar Negeri

123 Dalam Perpres ini UNHCR disebut sebagai Komisariat Tinggi Urusan Pengungsi yang merupakan terjemahan Bahasa Indonesia dari High Commisioner for Refugess, Pasal 1 butir 1, Perpres No. 125 Tahun 2016 tentang Penanganan Pengungsi dari Luar Negeri.

${ }^{124}$ Pasal 3, Perpres No. 125 Tahun 2016 tentang Penanganan Pengungsi dari Luar Negeri tahun 2015 .

${ }^{125}$ Contohnya pengungsi asal Vietnam pada tahun 70-an dan Rohingya serta Bangladesh pada 
mengenai tatacara penanganan dan penyelamatan pengungsi yang dilakukan dengan operasi pencarian dan pertolongan terhadap kapal-kapal yang membawa pengungsi. Operasi pencarian dan pertolongan pengungsi ini melibatkan TNI, Polri, Kemenhub, dan Badan Keamanan Laut. ${ }^{126}$ Setelah kapal yang memuat pengungsi ini ditemukan maka harus segera dilakukan tindakan darurat untuk menyelamatkan nyawa pengungsi, terutama jika pengungsi tersebut dalam kondisi darurat. ${ }^{127}$ Tindakan yang pertama kali harus dilakukan saat menemukan pengungsi adalah memindahkan pengungsi ke kapal penolong jika kapal akan tenggelam, membawa ke pelabuhan atau daratan terdekat jika aspek keselamatan nyawa Pengungsi dalam keadaan terancam, mengidentifikasi Pengungsi yang membutuhkan bantuan medis gawat darurat dan menyerahkan orang asing yang diduga Pengungsi kepada Rumah Detensi Imigrasi di pelabuhan atau daratan terdekat. ${ }^{128}$

Tidak jarang pengungsi yang sampai di negara tujuan atau negara transit ditemukan sudah tidak bernyawa lagi. ${ }^{129}$ Kejadian ini dapat disebabkan karena kapal yang membawa pengungsi tersebut tenggelam, atau karena kondisi dalam kapal yang kurang layak bagi kemanusiaan. Jika terjadi hal seperti ini maka lembaga yang melakukan operasi pencarian dan pertolongan pengungsi harus bekerja sama dengan tim identifikasi korban bencana Polri dan melakukan pendataan. ${ }^{130}$ Hasil identifikasi dan pendataan kemudian

${ }^{126}$ Pasal 7, Perpres No. 125 Tahun 2016 tentang Penanganan Pengungsi dari Luar Negeri

${ }^{127}$ Kapal-kapal yang digunakan oleh pengungsi untuk menyelamatkan diri dari negara asal yang dilanda konflik umunya hanyalah perahu sederhana yang tidak layak untuk pelayaran dalam waktu panjang dan menempuh jarak yang jauh. Kapal-kapal tersebut biasanya juga memuat penumpang melebihi kapasitas dan tidak membawa perbekalan yang memadai sehingga saat masuk ke Indonesia kondisi pengungsi biasanya sangat memprihatinkan karena kelelahan, kelaparan dan mengalami dehidrasi. Lihat Deutsche Welle Online, "Fenomena Arus Pengungsi Laut Tengah ke Eropa", http://www.dw.com/id/fenomena-arus-pengungsi-laut-tengah-ke-eropa/a-18411254, diakses tanggal 8 Oktober 2017

${ }^{128}$ Pasal 9, Perpres No. 125 Tahun 2016 tentang Penanganan Pengungsi dari Luar Negeri

129 Deutsche Welle Online, "20 Pengungsi Rohongya Tewas Tenggelam", http://www.dw.com/id/20-pengungsi-rohingya-tewas-tenggelam/a-40307883, diakses tanggal 8 Oktober 2017

${ }^{130}$ Pasal 14, Perpres No. 125 Tahun 2016 tentang Penanganan Pengungsi dari Luar Negeri 
disampaikan ke Kemenlu untuk disampaikan ke pada perwakilan diplomatik negara asal korban. ${ }^{131}$ Untuk kemudian dilakukan tindakan lanjutan apakah jenazah korban akan dimakamkan di Indonesia atau dikirimkan ke negara asal pengungsi. ${ }^{132}$

Perlindungan terhadap pengungsi selanjutnya yang diatur dalam Perpres No. 125 Tahun 2016 tentang Penanganan Pengungsi dari Luar Negeri adalah tentang penampungan dan hak-hak yang diterima pengungsi saat berada di penampungan. Rudenim berkoordinasi dengan pemerintah kabupaten dan kota dimana tempat pengungsi itu ditemukan untuk menyediakan tempat penampungan bagi pengungsi. ${ }^{133}$ Jika masih belum tersedia penampungan permanen maka harus disediakan akomodasi sementara untuk para pengungsi. ${ }^{134}$ Tempat penampungan tersebut dapat difasilitasi oleh IOM melalui kementerian Hukum dan HAM setelah berkoordinasi dengan Menkopulhukam. ${ }^{135}$ Fasilitas yang disediakan oleh IOM tersebut paling tidak harus meliputi penyediaan air bersih, pemenuhan kebutuhan makan, minum, dan pakaian, pelayanan kesehatan dan kebersihan dan fasilitas ibadah. ${ }^{136}$ Harus pula disediakan fasilitas untuk pengungsi yang berkebutuhan khusus meskipun tidak harus berada di wilayah yang sama dengan pengungsi lainnya ${ }^{137}$, yang dimaksud pengungsi berkebutuhan khusus dalam perpres ini

\footnotetext{
${ }^{131}$ Pasal 15, Perpres No. 125 Tahun 2016 tentang Penanganan Pengungsi dari Luar Negeri

132 Pasal 16, Perpres No. 125 Tahun 2016 tentang Penanganan Pengungsi dari Luar Negeri

${ }^{133}$ Pasal 24 ayat (1), Perpres No. 125 Tahun 2016 tentang Penanganan Pengungsi dari Luar Negeri

${ }^{134}$ Pasal 24 ayat (2), Perpres No. 125 Tahun 2016 tentang Penanganan Pengungsi dari Luar Negeri

135 Pasal 26 ayat (3), Perpres No. 125 Tahun 2016 tentang Penanganan Pengungsi dari Luar Negeri

${ }^{136}$ Pasal 26 ayat (5), Perpres No. 125 Tahun 2016 tentang Penanganan Pengungsi dari Luar Negeri

${ }^{137}$ Pasal 27 ayat (1), Perpres No. 125 Tahun 2016 tentang Penanganan Pengungsi dari Luar Negeri
} 
adalah pengungsi yang sedang sakit, hamil, anak-anak, pengungsi lanjut usia dan penyandang disabilitas. ${ }^{138}$

Tidak semua pengungsi yang ditemukan dan diselamatkan oleh pemerintah atau masyarakat Indonesia kemudian mendapatkan status sebagai pencari suaka atau pengungsi. Pemberian status ini dilakukan oleh UNHCR melalui persyaratan-persyaratan tertentu yang memakan waktu yang tidak sebentar. Untuk menjaga agar wilayah Indonesia tetap aman meskipun terdapat pengungsi di Indonesia, perpres ini megatur juga tentang tata cara pengamanan pengungsi di wilayah Indonesia. Pengamanan terhadap pengungsi dilakukan oleh Polri. ${ }^{139}$ Sedangkan pengawasan keimigrasian terhadap pengungsi dilakukan oleh petugas rudenim. ${ }^{140}$ Pengawasan terhadap pengungsi ini dilakukan sejak pengungsi ditemukan, dibawa ke tempat penampungan sampai pada pemberangkatan ke negara tujuan/ pemulangan ke negara asal/ pendeportasian. ${ }^{141}$

Berdasarkan uraian diatas, melalui Perpres No. 125 Tahun 2016 tentang Penanganan Pengungsi dari Luar Negeri pemerintah Indonesia berusaha bertanggungjawab terhadap pengungsi yang ada di wilayahnya. Perlindungan terhadap pengungsi diberikan sejak awal kedatangan hingga saat pengungsi meninggalkan negara Indonesia. Tidak semua pengungsi yang datang ke wilayah Indonesia kemudian bisa mendapatkan status sebagai pengungsi atau pencari suaka. Status sebagai pengungsi dan pencari suaka tersebut ditetapkan oleh UNHCR. Bagi pengungsi yang kemudian tidak diterima status pengungsinya, maka akan berstatus sebagai imigran illegal dan kemudian di

${ }^{138}$ Pasal 27 ayat (3), Perpres No. 125 Tahun 2016 tentang Penanganan Pengungsi dari Luar Negeri

${ }^{139}$ Pasal 32, Perpres No. 125 Tahun 2016 tentang Penanganan Pengungsi dari Luar Negeri

${ }^{140}$ Pasal 33 ayat (1), Perpres No. 125 Tahun 2016 tentang Penanganan Pengungsi dari Luar Negeri

${ }^{141}$ Pasal 33 ayat (2), Perpres No. 125 Tahun 2016 tentang Penanganan Pengungsi dari Luar Negeri 
tempatkan di rudenim hingga dideportasi ke luar wilayah Indonesia. ${ }^{142}$ Sedangkan bagi pengungsi yang diterima status permohonannya, maka pengungsi akan dikembalikan secara sukarela ke negara asalnya dan atau diberangkatkan ke negara tujuan. ${ }^{143}$

Perpres No. 125 Tahun 2016 tentang Penanganan Pengungsi dari Luar Negeri mengatur tentang pemulangan pengungsi ke negara asalnya secara sukarela dalam Pasal 38. Pemulangan sukarela ini tidaklah bertentangan dengan asas non-refoulement yang menjadi asas dasar Konvensi Pengungsi 1951. Dalam Konvensi Pengungsi 1951 yang dimaksud dengan refoulement adalah pengembalian pengungsi ke negara asalnya dengan daya paksa, dalam artian pengungsi tidak diberikan pilihan lain. Sementara dalam Pasal 38 pemulangan pengungsi ke negara asalnya dilakukan dengan sukarela, atas kemauan pengungsi itu sendiri. Dengan demikian, perpres ini tidaklah bertentangan dengan Konvensi Pengungsi 1951.

\section{PENUTUP}

\section{Kesimpulan}

Sampai saat ini, Indonesia belum meratifikasi Konvensi Pengungsi 1951 dan Protokol Pengungsi 1967 Indonesia memiliki posisi strategis karena terletak di antara benua Asia dan Australia, juga diantara Samudera Hindia dan Samudera Pasifik. Posisi ini membuat Indonesia sering dijadikan tempat transit bagi pengungsi dari kawasan yang sedang dilanda konflik (Timur Tengah dan Asia Selatan) menuju Australia. Sebenarnya, sebagai negara transit Indonesia tidak mempunyai dasar agar dapat dimintai pertanggungjawaban terhadap pengungsi yang masuk wilayahnya berdasarkan aturan internasional.

${ }^{142}$ Pasal 39, Perpres No. 125 Tahun 2016 tentang Penanganan Pengungsi dari Luar Negeri

${ }^{143}$ Pasal 37 dan 38, Perpres No. 125 Tahun 2016 tentang Penanganan Pengungsi dari Luar 
Meskipun demikian, Indonesia tentu tidak dapat lepas tangan begitu saja jika ada pencari suaka atau pengungsi yang masuk ke wilayah Indonesia. Penanganan pengungsi di Indonesia sebelum diundangkannya Perpres No. 125 Tahun 2016 tentang Penanganan Pengungsi dari Luar Negeri menggunakan aturan-aturan hukum yang berdimensi Hak Asasi Manusia. Aturan-aturan ini adalah UUD 1945, Pasal 28 G (2), Tap MPR No. XVII/MPR/1998, UU No. 5 Tahun 1998 tentang Pengesahan (Ratifikasi) Convention Againts Torture and Other Cruel, In Human or Degrading Treatment or Punishment, UU No. 37 Tahun 1999 tentang Hubungan Luar Negeri Pasal 25 (1) dan Pasal 27 (1) UU No. 39 Tahun 1999 tentang Hak Asasi Manusia Pasal 28 (1)

Dengan diundangkannya Perpres No. 125 Tahun 2016 tentang Penanganan Pengungsi dari Luar Negeri ini dapat ditarik kesimpulan bahwa Indonesia telah memiliki dasar hukum dalam penanganan pengungsi yang memasuki wilayah Indonesia dan tidak lagi terjadi kekosongan hukum. Diharapkan agar dengan Perpres ini Indonesia bisa lebih berperan dalam menangani masalah pengungsi di dunia internasional meskipun Indonesia belum meratifikasi Konvensi Pengungsi 1951 dan Protokol Pengungsi 1967. 


\section{DAFTAR PUSTAKA}

\section{A. Perjanjian Internasional dan Peraturan Perundang-undangan}

Geneva Convention on The Status of Refugees 1951

New York Protocol on The Status of Refugees 1967

Undang-Undang Dasar Negara Republik Indonesia Tahun 1945

Undang-Undang No. 5 Tahun 1998 tentang Pengesahan (Ratifikasi) Convention

Againts Torture and Other Cruel, In Human or Degrading Treatment or

Punishment

Undang-Undang No. 37 Tahun 1999 tentang Hubungan Luar Negeri

Undang-Undang No. 39 Tahun 1999 tentang Hak Asasi Manusia

Peraturan Presiden Republik Indonesia No. 125 Tahun 2016 tentang Penanganan

Pengungsi dari Luar Negeri

\section{B. Literatur}

Lembar Disposisi Direktur HAM dan Kemanusiaan, Naskah Akademik Rancangan Undang-Undang Pengesahan Konvensi Pengungsi, Jakarta:

Direktorat Kerjasama HAM Kementerian Hukum dan Hak Asasi Manusia Republik Indonesia, 2010

Wagiman, Hukum Pengungsi Internasional, Jakarta: Sinar Grafika, 2012

Rosmawati, "Perlindungan Terhadap Pengungsi/ Pencari Suaka di Indonesia (Sebagai Negara Transit) Menurut Konvensi 1951 dan Protokol 1967”, Jurnal Ilmu Hukum Universitas Syiah Kuala, Volume 17, Nomor 3, 2015

Fitria, "Perlindungan Hukum Bagi Pengungdi di Negara Ketiga: Praktik Indonesia”, Padjajaran Jurnal Ilmu Hukum, Volume 2 Nomor 1, 2015. 


\section{Media Online}

Sumandoyo, Arbi dkk, "Nasib Tanpa Negara Para Pencari Suaka di Indonesia", https://tirto.id/nasib-tanpa-negara-para-pencari-suaka-di-indonesia-cqgr, diakses tanggal 8 Oktober 2017

Deutsche Welle Online, "Fenomena Arus Pengungsi Laut Tengah ke Eropa", http://www.dw.com/id/fenomena-arus-pengungsi-laut-tengah-keeropa/a-18411254, diakses tanggal 8 Oktober 2017

Deutsche Welle Online, "20 Pengungsi Rohingya Tewas Tenggelam", http://www.dw.com/id/20-pengungsi-rohingya-tewas-tenggelam/a40307883, diakses tanggal 8 Oktober 2017

Institute for Criminal Justice Reform, "Melihat Perlindungan Pengungsi di Indonesia", $\quad$ http://icjr.or.id/melihat-perlindungan-pengungsi-diindonesia/, diakses tanggal 8 Oktober 2017

Press Release UNHCR 20 Juni 2016, http://www.unhcr.org/id, diakses tanggal 8 Oktober 2017

Puspita, Sherly, "Ini Alasan Para Pencari Suaka Tertarik Singgah di Indonesia", http://megapolitan.kompas.com/read/2017/06/21/06300541/ini.alasan.par a.pencari.suaka.tertarik.singgah.di.indonesia, diakses tanggal 8 Oktober 2017.

Rakyat Merdeka Online, "Perpres Perlindungan Pengungsi Harus Menjawab Permasalahan Pencari Suaka di Indonesia, http://dunia.rmol.co/read/2017/01/18/277051/Perpres-PerlindunganPengungsi-Harus-Menjawab-Permasalahan-Pencari-Suaka-di-Indonesia-, diakses tanggal 8 Oktober 2017

UNHCR Indonesia, UNHCR di Indonesia, http://www.unhcr.org/id/unhcr-diindonesia, diakses tanggal 8 Oktober 2017

UNHCR Indonesia, "Pengungsi”, www.unhcr.or.id, diakses pada 8 Oktober 2017 Wikipedia, Imigrasi. 